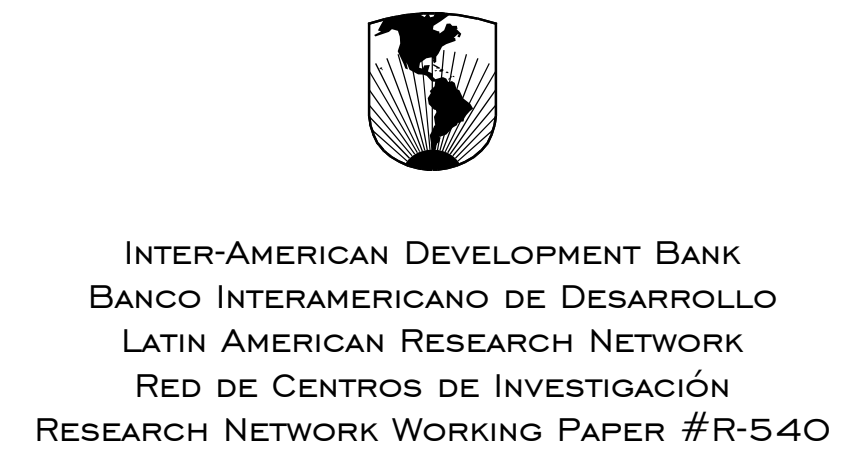

\title{
THe Role of Social Networks in the Economic OPPORTUNITIES OF BOLIVIAN WOMEN
}

\author{
BY \\ DANTE CONTRERAS* \\ DIANA KRUGER** \\ MARCELO OCHOA*** \\ DANIELA ZAPATA \\ * Universidad de ChILE \\ * * Universidad Católica de Valparaíso, Chile \\ $* * *$ Central Bank of ChILE \\ a UNITED NATIONS ECONOMIC COMISSION \\ FOR LATIN AMERICA AND THE CARIBBEAN
}

OCTOBER 2007 


\section{Cataloging-in-Publication data provided by the Inter-American Development Bank Felipe Herrera Library}

The role of social networks in the economic opportunities of Bolivian women / by Dante Contreras ... [et al.].

p. cm.

(Research Network Working papers ; R-540)

Includes bibliographical references.

1. Businesswomen--Bolivia. 2. Social networks--Bolivia. I. Contreras, Dante. II. InterAmerican Development Bank. Research Dept. III. Latin American Research Network. IV. Series.

HD6053 .R423 2007

331.4 R423----dc22

(C)2007

Inter-American Development Bank 1300 New York Avenue, N.W.

Washington, DC 20577

The views and interpretations in this document are those of the authors and should not be attributed to the Inter-American Development Bank, or to any individual acting on its behalf.

This paper may be freely reproduced provided credit is given to the Research Department, InterAmerican Development Bank.

The Research Department (RES) produces a quarterly newsletter, IDEA (Ideas for Development in the Americas), as well as working papers and books on diverse economic issues. To obtain a complete list of RES publications, and read or download them please visit our web site at: http://www.iadb.org/res. 


\begin{abstract}
*
This paper explores the role of social networks in determining the participation of Bolivian women in income-generating activities. The empirical analysis intends to explore the impact of this new social variable on the economic choices of women and its relative importance with respect to other individual characteristics, such as education or number of children in the household. The empirical framework defines social network as the average outcome of people living in the same neighborhood. Estimation results suggest that social networks are an effective channel through which women obtain access to salaried jobs, which are of higher quality than jobs as self-employers. In contrast, their male counterparts find a positive but statistically insignificant effect from social networks. When considering the sex of the contact, it is found that women in urban areas benefit from other women being employed, while in rural areas women benefit from the presence of more employed male workers.
\end{abstract}

Keywords: Gender, social networks, neighborhood effects.

JEL classification: J15, O18, J16, Z13.

\footnotetext{
${ }^{*}$ We would like to thank Hugo Ñopo, Andrea Moro, Ragan Petrie, Marco Castillo and seminar participants at IDB workshops in Washington, DC and Mexico City for their helpful comments. Special thanks to Alejandra Velasco for her able research assistance and to Alvaro Zapata for guiding us through the relevant sociology literature. This paper was financed by the IDB Latin American Research Network. Any errors or omissions are responsibility of the authors. Contreras is the corresponding author: dcontrer@econ.facea.uchile.cl.
} 


\section{Introduction}

Female labor market discrimination has important welfare implications in the developing world, where labor market earnings are the main component of households' income, especially among poor families. Women are important contributors to total household income, and in many cases they carry the burden of raising their family alone: during the 1990-2004 period, between 20 to almost 50 percent of households were headed by women in developing countries, ${ }^{1}$ earning between 25 to 30 percent less than men with similar education and labor market experience. Thus, women's labor choices and outcomes have immediate effects that may make the difference between living in poverty or not. More generally, in less developed countries gender inequality is a widespread phenomenon that enhances poverty and decreases social mobility.

Research on gender gaps in the labor market has traditionally sought explanations on the characteristics and preferences of individual workers or employers. One strand of the literature attributes the associations between workers' sex and their labor market outcomes to sex differences in training, experience, age, marital status or career commitment. Others focus on employers' preferences for workers of one sex over the other (taste discrimination) or on employers' beliefs that workers of one sex or the other are more costly or less profitable to employ (statistical discrimination). ${ }^{2}$ Even though measuring discrimination is not an easy task, the evidence is that, net of human capital characteristics and a variety of other control variables, men out-earn women, have better benefits, more on-the-job training and hold more complex jobs with more authority. Moreover, there is no evidence of a decrease in labor market unexplained gender differences as supporters of market-based theories would expect. ${ }^{3}$

Recent research in the fields of sociology and economics has shown that in addition to individual characteristics, social networks play an important role in the job matching process since a very important fraction of workers find jobs through friends and relatives. ${ }^{4}$ Social interactions have externalities, in which the actions of a reference group affect an individual's

\footnotetext{
${ }^{1}$ World Bank (2006). Data for the 1990-2004 period; excludes countries with traditional societies where women play minor roles.

${ }^{2}$ A comprehensive survey of the literature can be found in Altonji and Blank (1999), while Moreno et al. (2004), Ñopo (2004), Núñez and Gutiérrez (2004) and Bravo et al. (2006) are examples of more recent empirical work on discrimination for Latin America.

${ }^{3}$ Ñopo (2004, 2007), Berhardt, Morris and Handcock (1995), and Arrow (1998).

${ }^{4}$ Rees (1966) and Granovetter $(1973,1995)$ suggest that in the United States more than 50 percent of all new jobs were found through friends, relatives, neighbors or occupational contacts rather than through formal means.
} 
preferences. ${ }^{5}$ If men and women use their social networks differently and if the networks have different characteristics, then the interactions with their peers would have different effects on their employment patterns and the quality of jobs they can access. This, in turn, could have important welfare effects on families who live in developing countries.

Social network theory differs from traditional studies that assume that only individual characteristics influence individuals' economic decisions: personal characteristics as well as their relationships and ties with other actors within the network matter. Hence, in the labor market context, the structure of individuals' social networks turns out to be a key determinant of (i) who gets a job and who gets which job, (ii) how patterns of unemployment relate to gender or ethnicity, and (iii) the incentives that individuals have to educate themselves and to participate in the workforce (Jackson, 2003).

Theoretical models of social networks distinguish two mechanisms through which social contacts impact on the functioning of the labor market. First, employers may reduce uncertainty about prospective worker's productivity through referrals obtained from firms or workers. Second, worker's connections disseminate job information within the supply side of the labor market through word-of-mouth communication. In his seminal work Montgomery (1991) allows workers and firms to choose between formal and informal hiring channels, and concludes that workers who are well connected might fare better than workers with no social ties to highability workers, even while holding numerous ties to low-ability workers. More recently, models by Calvó-Armengol and Jackson (2002) and Calvó-Armengol (2004) allow workers to rely both on own search effort and on information exchange with their social circles to find jobs. They conclude that information passed from employed individuals to their unemployed acquaintances makes it more likely that these acquaintances will become employed, and that the duration and persistence of unemployment can be understood as social effects: the longer an individual is unemployed the more likely it is that her social environment is associated with unfavorable unemployment prospects. Calvó-Armengol and Jackson (2004) find that the likelihood of dropping out of the labor force is higher for individuals who have few acquaintances or whose social contacts have poor employment experience.

Empirical studies suggest that social networks do have significant effects on employment outcomes. Case and Katz (1991) find a correlation between youth joblessness and the joblessness

\footnotetext{
${ }^{5}$ Scheinkman (forthcoming 2008).
} 
of neighbors. Topa (2001) and Conley and Topa (2002) find that social interactions can indeed explain the persistent correlations in patterns of unemployment in US cities. Weinberg et al. (2004) show that one standard deviation improvement in neighborhood social characteristics and in job proximity raises individuals' hours worked by six per cent and four per cent on average, respectively. Similarly, Van Ham and Buchel (2006) find that those willing to work find it easier to do so if they live in regions with low regional unemployment rates.

The empirical literature has also found evidence of differences in the characteristics of men's and women's social networks, which is the result of differences in the social-structural locations of women and men, and which in turn have effects on the access to information about job vacancies. Men are more likely to have wider-ranging networks consisting of work-centered networks (i.e., colleagues and co-workers), while women are more likely to have kin-centered networks. ${ }^{6}$ While men are more likely to have higher-status social positions in communities, higher-status jobs, and fewer domestic responsibilities, women work in jobs with less socioeconomic status and professional responsibilities and have more domestic responsibilities, constraining their possibilities to form networks with people in high-status jobs, which creates network disadvantages for women.

Empirical results suggest that female-dominated social networks are associated with lower-quality employment. For instance, Mencken and Winfield (2000) find that women who found their jobs through male informal contacts were less likely to work in female-dominated occupations, which compared to non-female-dominated jobs offer lower wages, limited training, fewer opportunities for advancement, less autonomy, and more limited authority. Beggs and Hurlbert (1997) find that the gender of the informal contact affects the occupational status: women whose contacts are other women work in occupations with lower socioeconomic index. Finally, Petersen, Saporta and Seidel (2000) find that race and gender have a strong impact on the likelihood of having a second interview and on the increase in the salary offer. ${ }^{7}$

The aim of this paper is to examine the role of social networks in employment outcomes of Bolivian women vis-à-vis men, and to explore its relative importance with respect to individual characteristics, with a special concern for the quality of employment that they are able

\footnotetext{
${ }^{6}$ Brass (1985), Hanson and Pratt (1991), McPherson and Smith-Lovin (1982, 1986).

${ }^{7}$ However, once they control for the referral method, sex and race effects disappear.
} 
to obtain. By including social interactions in the analysis, we expand previous studies that only controlled for personal characteristics to explain women's economic choices.

Bolivia is one of the poorest countries of Latin America, with a per capita GDP of less than US\$1,000 and with high levels of income inequality. Additionally, serious gender biases are prevalent in its labor market; for instance, between 1989 and 2002 unemployment and lowquality jobs increased, yet women's unemployment rates were consistently higher than men's. And although female labor force participation rates have increased, the entry of more women into the Bolivian job market has not translated into quality jobs: by the end of the period 80 percent of employed women worked in the informal sector, compared to 60 percent of employed men, and 75 percent of employed rural women did not receive any income for their work, which limits their possibilities to escape from poverty. ${ }^{8}$ Furthermore, more than 50 percent of Bolivian women supply more than half of their family income, whilst the average hourly wage of women with college education is 40 percent below that of their male counterparts (Bravo and Zapata, 2005). Notwithstanding these gender inequities, without the contribution of women to household income poverty rates would have been 11 percentage points higher in 2002.

The rest of the paper unfolds as follows. The next section presents our methodological approach and identification strategy, followed by a section that describes the data used and summary statistics. Section 4 contains the estimation results, and the last section concludes with final remarks and policy recommendations.

\section{Empirical Framework}

\subsection{Social Network Measures}

Empirical social network studies have typically defined a network along geographic or cultural proximity of a group of individuals. The empirical work has faced the difficult task of explaining if the observed correlation in the behavior of individuals who are physically or socially close is because they share the same sources of information or because they learn from one another's behavior. The difference between the two of them is that the latter is really a social interaction, while the first simply reflects the fact that the group is affected by similar shocks (a more detailed explanation of the problems that can affect the empirical literature and the potential solutions will be explained in more detail in the following section).

\footnotetext{
${ }^{8}$ See http://www.cepal.cl/mujer.
} 
Furthermore, economic studies that define network effects as neighborhood effects recognize that the ties with one's neighbors are weaker than the ties with friends or kin, and it is precisely this kind of ties that is more conductive to generating useful information about jobs. The literature on social networks acknowledges that a key characteristic determining the effect of job networks on finding employment is the strength of social ties. Granovetter $(1973,1995)$ argues that "weak" ties such us colleagues or acquaintances are a richer source of information about job openings than close family or friends ("strong” ties), because weak ties link various groups in social space, increasing the amount of non-redundant information. In contrast, strong ties connect similar people who are less likely to offer the job searcher information that she does not already have. In a more general context, strong and weak ties have different effects and different benefits. Strong ties are an important source for understanding and support, while weak ties provide access to miscellaneous resources. ${ }^{9}$

In this paper we use a reference group definition based on physical proximity as a measure of an individual's social network. The underlying idea is that agents exchange information about job openings more frequently with people who live physically close. Let each individual $i$ be a member of a peer group which is indexed by $g$ and is comprised of $n_{g}$ individuals. We assume that each group is comprised by individuals that live in a common neighborhood, thus $g=\{$ neighborhood $\}$. We observe the (binary) outcome of each individual $y_{i, g}=\{0,1\}$, which represents the labor market outcome under study. We define the social network as the average outcome of the other members in the group:

$$
\bar{y}_{i, g}=\sum_{\substack{j=1 \\ j \neq i}}^{n_{g}} \frac{y_{j, g}}{n_{g}-1}
$$

Since $y_{j, g}$ is the individual's labor market outcome (e.g., whether she is employed), then $\bar{y}_{i, g}$ is the (left-out) group average outcome.

Of course, social networks need not to be strictly geographic; networks also develop along other dimensions, such as gender. Straits (1998) finds that that men and women tend to use same-sex contacts in order to find to a job, so in order to obtain an additional measure of social networks we combine the gender social metric with our physical measure of networks. Thus, an

\footnotetext{
${ }^{9}$ Hirsh et al. (1990), Cattell (2001), Granovetter (1973).
} 
individual's sex is considered as an additional indicator of social proximity, so that another measure of social network can be given by,

$$
\bar{y}_{i, g}=\sum_{\substack{j=1 \\ j \neq i}}^{n_{g}} \frac{w_{i, j} \times y_{j, g}}{n_{g}-1}
$$

where individual $i$ gives a positive weight $w$ equal to 1 to every agent's outcome $j$ who belongs to her same sex, otherwise the outcome is assigned a weight equal to zero. Therefore, if social networks develop along gender lines, the employment outcomes of a female will be affected by the share of women peers with whom she can share information about job offers.

\subsection{Empirical Model}

Our econometric model follows closely the empirical models presented in the literature studying social interaction effects where the outcome of an individual is not only explained by her personal characteristics, but it is also influenced by the average outcome of her reference group, namely the social network variable. ${ }^{10}$

Each individual's labor market outcome depends on a combination of individual-specific and group-specific factors. The individual-specific factors are comprised by observed $\mathbf{x}_{i}$ (e.g., experience, marital status, number of children). Group-specific factors are partitioned into observed group-level characteristics $\mathbf{z}_{g}$ (e.g., poverty rate in the neighborhood) and those that are unobserved, $\zeta_{g}$ (e.g., employment opportunities in the neighborhood), and the average choice in the group $\bar{y}_{i, g}$. Under these assumptions, the labor market outcome of each individual can be described by the following probability model,

$$
\mathbf{P}\left(y_{i, g}=1 \mid \mathbf{x}_{i, g}, \bar{y}_{i, g}, \mathbf{z}_{g}\right)=\mathbf{F}\left(\mathbf{x}_{i, g} \boldsymbol{\beta}+\gamma \bar{y}_{i, g}+\mathbf{z}_{g} \boldsymbol{\delta}+\zeta_{g}\right)
$$

where social interactions are captured by the characteristics of the group $\mathbf{z}_{g}$ and, the social network variable represented by the average outcome (employment rate) of the other members in the group $\bar{y}_{i, g}$.

\footnotetext{
${ }^{10}$ Case and Katz (2001), Sacerdote (2001), Bertrand et al. (2001).
} 
Our model embeds three alternative hypothesis that can explain the correlation in the labor market outcomes of individuals who are in physical proximity to one another: endogenous interactions, exogenous or contextual interactions, and correlated effects (Manski 1993, 1999). In the presence of endogenous interactions the probability of an individual of obtaining a job increases with the fraction of her employed peers $\bar{y}_{i, g}$. Consequently, in the presence of endogenous interactions, the coefficient accompanying the group's average choice will be greater than zero $(\gamma>0)$, implying that social contacts have a positive impact on labor market outcomes. This variable captures the idea that social contacts mediate propagation of rich and reliable information among individuals, thereby helping workers to find jobs, and employers to find employees (Calvó-Armengol, 2004). Consequently, interaction with more individuals that are strongly attached to the labor market (i.e., larger $\bar{y}_{i, g}$ ) leads to a reduction in the cost of finding information about job availability and/or to an increase the individual's job market referrals, increasing the probability that the individual finds a job.

In addition to the direct impact of social networks, we may expect that an individual's outcome might be also influenced by the average personal characteristics of her reference group. For instance, an individual related to a cluster with a high socioeconomic status might increase her employment opportunities either because a member of the group may employ her, or because the member refers her to another employer. If this is the case, we are in the presence of contextual effects; hence, the effect is through the group characteristics and not through group outcomes.

We may also believe that individuals in the same group tend to behave similarly because they sort into neighborhoods or face similar institutional environments, what Manski calls correlated effects. For example, if the neighborhood where the individual and his group inhabit has better access to jobs, the individual's likelihood of obtaining a job as well as the average employment rate of the group will increase.

In order to draw meaningful public policy implications, it is very important to distinguish between these three effects. Moffitt (2001) argues that both endogenous and contextual effects imply that an individual's outcome is influenced by her group; therefore, both represent real social interactions. Nevertheless, if endogenous effects are present then the aggregate impact of a policy intervention will be larger than the individual-level impact, giving rise to a "social 
multiplier," which will not happen if the social interaction is through contextual effects (Soetevent, 2006). In the context of this paper, a "social multiplier” occurs when an employed person raises the probability of being employed for the rest of the individuals on her group. Correlated effects, on the other hand, do not imply a social multiplier or that social groups matter.

\subsection{Identification Strategy}

Even if we have compelling evidence of correlations in the employment status of individuals who are in physical proximity to one another, we wish to know what explains such correlations. The presence of contextual and endogenous effects makes it difficult to disentangle the true impact of social networks on the employment opportunities of individuals. In this subsection we present our identification strategy and how it addresses these problems.

The first problem that arises in the empirical study of social interactions is the reflection or simultaneity problem. As explained in Sacerdote (2001) and Gaviria and Raphael (2001), the reflection problem arises due to the fact that social interactions-endogenous and exogenousnot only affect the individual's outcomes but also impact the outcomes of other agents in the group simultaneously. An econometrician who observes simply the final outcome may overcome the simultaneity problem by using an instrumental variables approach. The instrument that allows identification should be correlated with the social network variable but should not determine the labor market outcome of the individuals (Soetevent, 2006; Gaviria and Raphael, 2001).

The second major difficulty in identifying the effect of social interactions concerns the possibility that unobserved group or neighborhood effects exist. The presence of unobservable group effects can, if not accounted for, lead to spurious conclusions concerning the presence of social interactions. For instance, suppose some neighborhoods are affected by a positive shock and have more availability of jobs. If one calculates the correlation between an individual's labor market outcome and the average neighborhood outcome, this correlation may be positive not because of any influence of social networks, but also because average neighborhood employment may be itself correlated with the availability of jobs within the neighborhood. Again, the presence of some non-observable group-specific component that is correlated with the 
exogenous characteristics of the individuals will generate a non-zero expected value of the error term.

Soetevent (2006) asserts that the common empirical approaches to solve or circumvent these problems rely on (i) the use of data in which agents are assigned in a random fashion to reference groups; (ii) the use of data where a fraction of agents within the group are given a treatment; (iii) the use of a functional form that explicitly accounts for inter-group differences by adding group-specific fixed effects and (iv) the use of instrumental variables. Given the nonrandom nature of our data set, we rely on the last two strategies to attenuate the bias in the estimated effect of the social network and contextual effects.

First, following the strategy presented in Bertrand, Erzo and Sendhil (2001), we regard unobserved group effects as fixed effects. We assume that the most important unobservable effects arise due to characteristics such as economic shocks in certain regions that influence the job availability in a group of nearby neighborhoods. For instance, a positive shock in an area will have the same effect on its neighborhoods. Therefore, we take advantage of geographic variation, allowing the inclusion of group-geographic fixed effects that include a number of neighborhoods which are very homogenous. More specifically, we include fixed effects at the municipal level, which are areas concentrating several similar neighborhoods. We therefore estimate

$$
\mathrm{P}\left(y_{i, g}=1 \mid \mathbf{x}_{i, g}, \bar{y}_{i, g}, \mathbf{z}_{g}\right)=\mathrm{F}\left(\mathbf{x}_{i, g} \boldsymbol{\beta}+\gamma \bar{y}_{i, g}+\mathbf{z}_{g} \boldsymbol{\delta}+\zeta_{a}\right)
$$

where, $\mathbf{x}_{i, g}$ is a vector of individual characteristics, $\bar{y}_{i, g}$ is the average outcome observed by the other members of the group, $\mathbf{z}_{g}$ is a vector containing average characteristics of the group members, and $\zeta_{a}$ are area fixed effects. The inclusion of these last two variables allows us to control for the presence of contextual effects and the primary sources of correlated effects, helping to attenuate the bias in the estimated effect the social network variable.

As a second estimation strategy and to check the robustness of our results, we attempt to identify the social network effect finding an adequate instrumental variable in order to control for non-observable characteristics of the neighborhood and controlling for possible endogenous group formation (Moffitt, 2001). This strategy not only helps us to control for possible sources of correlated effects but also to overcome the reflection problem as we explain below.

Following Bayer and Ross (2006), our strategy comprises a two-step procedure. In the first step, we will try to eliminate the correlation between the group component of the error term 
and the individual attributes included in the regression by finding an adequate instrument to proxy the non-observable characteristics of the neighborhood. Let $\theta_{g}$ be a variable that summarizes all of the group contribution to the individual outcome, where $\theta_{g}=\gamma y_{i, g}+\mathbf{z}_{g} \boldsymbol{\delta}+\zeta_{g}$. For instance, a neighborhood that has a high employment rate, a positive economic environment, and inhabitants with high socioeconomic status can be considered a neighborhood $\mathbf{P}\left(y_{i, g}=1 \mid \mathbf{x}_{i, g}, \bar{y}_{i, g}, \mathbf{z}_{g}\right)=$ of high quality, i.e., high $\theta_{g}$. Bayer and Ross (2006) demonstrate that neighborhoods with increasing values of $\theta_{g}$ are also ordered monotonically in terms of neighborhood housing prices $p_{g}$. This monotonic relationship implies that prices serve as a perfect control function for $\theta_{g}$. Therefore, we can obtain a proxy for unobserved neighborhood characteristics from the average residual for each neighborhood arising from a housing price equation regression.

$$
p_{i, g}=\mathbf{H}_{i, g} \boldsymbol{\varphi}+\gamma \bar{y}_{i, g}+\mathbf{z}_{g} \boldsymbol{\delta}+v_{i, g}
$$

where $\mathbf{H}_{i, g}$ is a vector of housing unit attributes that absorbs any aspect of prices explained by housing characteristics. Once we estimate equation (5) we can obtain an estimated control function for the unobservable neighborhood attributes $\left(\hat{\zeta}_{g}\right)$ by averaging the unexplained portion of house prices for each neighborhood. Then, we can replace it in equation (3) obtaining,

$$
\mathbf{P}\left(y_{i, g}=1 \mid \mathbf{x}_{i, g}, \bar{y}_{i, g}, \mathbf{z}_{g}\right)=\mathbf{F}\left(\mathbf{x}_{i, g} \boldsymbol{\beta}+\bar{y}_{i, g}+\mathbf{z}_{g} \boldsymbol{\delta}+\hat{\zeta}_{g}\right)
$$

The second part of the strategy is designed to address the likely correlation of the error term that arises from the non-random sorting of household into neighborhoods or the presence of unobservable individual characteristics. As shown in Bayer and Ross (2006), the presence of non-random sorting generally will imply correlation between neighborhood attributes $\left(\bar{y}_{i, g}, \mathbf{z}_{g}\right.$ and $\hat{\zeta}_{g}$ ) and the error term. To overcome this problem, they suggest using as an instrument the average values of observed neighborhood characteristics for individuals with the same observable characteristics. The proposed instruments are predictive of location because similar individuals make similar neighborhood choices, and they are not correlated to individual's 
unobservable preferences because they have been constructed using observable characteristics which are assumed to be uncorrelated with non-observable individual variables.

Moreover, our second estimation strategy also deals with the simultaneity or reflection problem. As in Gaviria and Raphael (2001), our instrument for the social network is correlated with this variable, but since it is only a good predictor for the individual's location, it does not impact labor market outcomes. Therefore, this identification strategy will allow us to draw conclusions about the extent of the effects of social network effects.

The two empirical identification strategies are intended to isolate endogenous effects from exogenous and correlated effects. However, it is still possible that we cannot identify the sole effects of social networks, and in that case our results will overstate their role. This caveat notwithstanding, in this case our results will still be robust to the presence of social interactions since both strategies are particularly satisfactory at removing correlated effects (Bayer and Ross, 2006). Therefore, the statistical significance of the social network variable still stresses the importance of group effects in labor market outcomes beyond individual characteristics.

\section{Data and Summary Statistics}

This study uses two sources of information. First, individual-level data are obtained from the 2001 round of Bolivia's national household survey (MECOVI), which is administered by the National Statistical Institute (INE) during the months of November and December of each year. MECOVI is a nationally representative survey that collects detailed data on the characteristics of 25,166 individuals and 5,845 households. These data allowed us to obtain relevant information on individual's labor market outcomes, individual characteristics, household's composition and dwellings characteristics. Additionally, we were able to identify the neighborhood where each individual lives.

The MECOVI survey is not representative at the neighborhood level, therefore, we use the Bolivian census to obtain our proposed measure of social networks and several group characteristics. The census was conducted in August of 2001 and contains basic information on households, individual and employment characteristics of each member of the household. According to the census, Bolivia has a population of 8,274,325 people divided into nine departments and 314 municipal governments. While the MECOVI covers all nine departments, it only includes 211 municipal governments; therefore, our final database contains only those 
municipalities covered by both the census and the MECOVI. The final database contains individuals residing in 576 neighborhoods around the country.

There are two benefits of using data from both, the household survey and the census. First, the MECOVI survey contains a richer set of household characteristics and employment outcomes, in contrast to the census where the number of variables is limited. Second, the census contains data that is representative at the neighborhood level, providing us with information about the group that surrounds each individual, which cannot be obtained from the MECOVI survey.

Our analysis is based on data for 1,679 females and 2,299 males, aged 25-60 years old. We restrict our sample to this range of age since we do not want our results to be affected by the schooling or retirement decisions. In our sample, by age 25 the male participation rate is over 90 percent, while the female rate is above 65 percent. This result remains true for the 25-60 year-old range.

In Bolivia’s labor market there are important differences between urban and rural areas. In rural regions, agriculture is one of the most important activities. In particular, subsistence agriculture, which does not demand high skill labor, constitutes a significant fraction of the work performed in rural areas. As a result, the participation and employment rates in this area are typically high (see Table 1). Even though nearly all rural women and men are employed (over 98 percent), about 72.3 percent of female workers and 35.3 percent of male workers are nonremunerated. Among remunerated workers, 79 percent of men work as self-employers and 77 percent of women do so. Conversely, in urban areas only 18.1 percent of women and 11.0 percent of men perform non-remunerated activities. Most men who work for pay are wage workers (59 percent), whereas women are mostly self-employed (55 percent). ${ }^{11}$

Table 2 summarizes selected characteristics of wage/salary workers and independent workers. We can see that wage workers earn more than self-employed, both in urban and rural areas (above 78 percent). Men receive higher hourly earnings than women, except among the self-employed in rural areas. Rural self-employed receive the same hourly income independently of their sex, yet both the hourly and monthly income of this group of workers is very low compared to that of their wage/salary counterparts. Furthermore, 32 percent of wage workers are

\footnotetext{
${ }^{11}$ Since a very small fraction of the population works as an employer we perform our analysis considering only wage/salary workers and independent workers.
} 
affiliated with private social security (AFP), while only 1.8 percent of self-employed workers are. Women wage workers, however, are affiliated at a higher percentage than men wage workers.

Wage workers are more educated than self-employed. In particular, female wage workers are more educated than men, but this difference does not translate into higher or even equal earnings. The self-employed are older and work fewer hours than wage workers. Moreover, in rural areas those workers are mostly indigenous. Low wages, low affiliation with social security and low levels of education of workers suggest that in Bolivia self-employment is a low quality job compared to wage/salary work.

Selected characteristics describing the neighborhoods in which our sample of individuals lives are presented in Table 3. Neighborhoods in urban areas contain a low concentration of indigenous population (28 percent), and on average 45 percent of individual living in urban neighborhoods live in poverty. ${ }^{12}$ In contrast, neighborhoods in rural areas contain a high proportion of indigenous people (67 percent) and strikingly, on average 90 percent of individuals in rural neighborhoods are poor according to the Basic Unsatisfied Needs Index.

Regarding labor market characteristics, both rural and urban neighborhoods have the same fraction of employed people between 25 and 60 years old (67 percent). However, there are important differences between neighborhoods in rural areas, as implied by the large standard deviation. Important gender differences, also between urban and rural areas arise, when the share of people working as wage/salary workers is considered. In urban area neighborhoods, on average, about 33 percent of people aged 25 to 60 works as a wage/salary worker, whereas only 12 percent of people in rural neighborhoods work as wage workers. In both rural and urban neighborhoods, a smaller share of women have salaried employment.

\section{Empirical Results}

In this section we present the results of estimating equation (4) using a normal probability model for the two different labor market outcomes under study and the instrumental variables model using equation (6). We are interested in exploring the role of social networks in (i) the probability of participating in the labor market vs. not participating in the labor market, and (ii) the probability of working in a wage/salary job vs. working in an independent (self-employed)

\footnotetext{
${ }^{12}$ This poverty rate was calculated using the Basic Unsatisfied Needs approach at the neighborhood level.
} 
job. We perform all the estimations using observations for women and men separately. Additionally, due to the differences between the urban and rural labor markets acknowledged in the previous section we also report these results separately for these two areas.

The social network variable is calculated using equation (1). When the individual outcome is labor force participation, we consider the social network as the share of individuals in the neighborhood that are employed. We consider only employed individuals because unemployed ones will not be an effective information channel, since it is likely that if they have information about a job opening they will keep it for themselves. Moreover, a larger share of employed individuals may encourage people to participate in the labor market, while high unemployment rates may have the opposite effect. When the relevant outcome is wage/salary worker vis-à-vis self-employed, the social network variable is the share of individuals in the neighborhood who are wage workers.

In a separate set of regressions, we compute the social network variable considering the sex of the contacts within the neighborhood in order to test the hypothesis that social networks are formed along gender lines. Hence, we include the average outcome of females and males in the neighborhood as separate regressors. If women (men) tend to have same-sex contacts then, the average outcome of women (men) will have a significant and positive effect on the same-sex individual's outcome. On the other hand, if social networks of women include both men and women, then both employed men and women will experience a positive impact.

We also control for personal characteristics, households characteristics and include relevant variables to capture the impact of contextual effects. The vector of individual characteristics includes labor market experience (proxied by age), education of the individual, a dummy if the individual is a household head, a dummy if the individual is married and a dummy if she belongs to an indigenous group. Household demographic composition is captured by including variables for the number of young children (less than 6 years old), youngsters (between 6 and 18 years old), adults (between 19 and 60 years old) and elderly (60 years or older) in the household. To capture exogenous effects, we control for the poverty of the neighborhood measured as the share of inhabitants with unsatisfied basic needs in education, housing and health. We also include the share of indigenous inhabitants in the neighborhood and the share of people between 25 and 60 years old in the neighborhood that have secondary education or more 
years of education. Finally, we include municipal fixed effects to control for neighborhood unobservables.

Tables 5 to 8 present our results. Odd-numbered columns contain the results for the probability model with municipality fixed effects, and the instrumental variable estimations are displayed in even-numbered columns.

\subsection{Individual Characteristics and Employment Outcomes}

\section{Female Sample}

Tables 5 and 6 report the results of estimating a probability model for female labor market participation in urban and rural areas, respectively. The variables controlling for individual characteristics display the expected signs. Being a household head increases the probability of labor market participation, both in urban and rural areas. Experience (proxy by age) has a positive but decreasing effect on labor market participation. In urban areas having more education increases the likelihood of joining the labor market, but being married decreases it. Both of these effects are not significant in rural areas.

The results of the probability model of working as a wage/salary worker for women in urban and rural areas are presented as well in Tables 5 and 6. Regarding personal characteristics, we find that in urban and rural areas more educated women have more likelihood of performing wage/salary work. In urban areas marriage and the presence of small children has a negative effect on the probability of being a wage worker, implying that in urban areas less educated married women living with small children are more likely to be independent workers.

\section{Male Sample}

In urban areas being a household head, indigenous and having small children increases the probability of participating in the labor market. Experience has a non-linear effect, as in the female sample. None of these variables are significant in the rural sample, which comes as no surprise since almost all rural men are participating in the labor market.

In urban and rural areas better-educated men are more likely to be wage/salary workers. In contrast to women, in urban areas neither the marital status nor the family composition are important variables at the time of explaining the probability of having a salaried job. On the contrary, in rural areas married men have a higher probability of self-employment. 


\subsection{The Role of Social Networks and Exogenous Effects on Employment Outcomes}

\section{Female Sample}

After controlling for area fixed-effects and contextual characteristics, we find that the social network (i.e., the fraction of employed inhabitants in the neighborhood) influences positively though not significantly the probability of participating in the labor market both in rural and urban areas (Table 5 and 6). This result remains when we consider the fraction of women and men employed separately.

On the other hand, the results in Tables 5 and 6 also indicate that the social networkmeasured as the fraction of wage/salary workers in the neighborhood-has a positive effect on the probability of holding this type of job, both in urban and rural areas. Furthermore, when we consider the sex of the contact on the definition of the social network we find that urban females benefit from other women being employed as wage workers, while the share of male wage workers in their neighborhood has a not statistically significant effect. In contrast, in rural areas the probability of having a salary work for a woman increases as the share of men wage workers increases, whereas the percentage of women does not have a statistically significant effect.

Regarding contextual effects, we find that as the percentage of poverty increases the percentage of women participating in the labor market decreases, probably reflecting the fact that women living in poor households cannot buy domestic services that allow them to have more time to participate in the labor market. We also found a negative correlation between the share of people with completed high school education completed in the neighborhood and the probability of participating in the labor market. If high levels of education are correlated with higher levels of income it is possible that the participation of women has an inverted " $U$ " shape in income, with low levels of participation at low levels of income and also with low levels of participation at higher income levels.

In rural areas, as the fraction of indigenous population in the neighborhood increases the probability of participating in the labor market is higher. The percentage of indigenous population is also positive correlated with the likelihood of being self-employed. A possible explanation is that the concentration of indigenous population may itself function as a type of network, and therefore a larger share of indigenous neighbors may imply a larger network in which to obtain information about possible job prospects (see Contreras, Kruger and Zapata, 
2006). The strength of this correlation is higher-both in magnitude and statistical significance-in rural areas.

\section{Male Sample}

Social networks have a positive and significant effect on the probability that urban men participate on the labor market (Table 7). Furthermore, when we consider the fraction of women and men employed separately we found that men who live in neighborhoods with a larger fraction of employed men have a higher likelihood of participating in the labor market, while the percentage of employed women is not a statistically significant variable for this outcome.

When we explore the impact of social networks on the probability of having a wage/salary job we find that social networks have a positive effect on the probability that rural men hold this type of job. When we consider the sex of the contact the results indicate that men in both rural and urban areas benefit from having men neighbors employed as wage workers; nevertheless, this result loses its statistical significance once we use instrumental variables in order to control for the quality of the neighborhood and the possibility of sorting. Therefore, caution should be taken when looking as this result.

The only statistically significant contextual effect is the percentage of indigenous population in rural areas, which increases the probability of being self-employed.

\subsection{Marginal Effects}

We depict the probability of having a wage/salary job for a person with average values on all variables but changing the value of her social network (see Figure 1). Looking at the left panel in Figure 1 we can see that slight increments in the share of salaried workers in the neighborhood increases dramatically the probability of a women to find a job as a wage/salary worker. In contrast, men seem to obtain only small benefits from social contacts. In rural areas, the benefits of social networks are only slightly larger for women than for men.

Figure 2 depicts the probability of working as a wage/salary worker as the share of male and female wage/salary workers changes, keeping all other variables at their average levels. The results indicate that in urban areas, women benefit the most from same-sex contacts. This is evident when looking at the first panel in Figure 2, which shows the probability of a women working as a wage worker increases importantly only when the share of same-sex wage workers increases within the neighborhood. 
Females living in rural areas benefit from both male and female social networks. As shown in the third panel in Figure 2, the probability that a female urban worker is a wage/salary worker increases with the share of both, male and female employed wage/salary workers. In contrast, the probability that a male works as a wage/salary worker increases only as the share of same-sex wage workers increases, whereas females in urban areas experience a negative but insignificant effect.

Men also benefit importantly from other men being salaried workers in their neighborhood, but they present a small but negative effect from the share of working females (see second panel in Figure 2).

\subsection{Intensity of the Social Network Effect among Different Populations}

Previous literature indicates that the intensity of use of social networks varies among different demographic groups. Elliot (1999) found that workers with less education and located in high poverty rate neighborhoods are more likely to use informal contacts. In contrast, according to Ioannides and Loury (2004) more educated job seekers are less likely to use friends or relatives to find a job.

We are interested in exploring if low skill men and women use social networks with more or less intensity than the rest of the population. The results in Table 9 indicate that men and women with incomplete primary education use social networks more intensively to find a wage/salary job, both in urban and rural areas. This result is consistent with previous findings that labor market referrals are used less intensively by individuals with higher levels of education (Bayer, Ross and Topa, 2004; Bayer and Ross, 2006).

\section{Final Remarks and Policy Implications}

Traditionally, when studying labor market outcomes only individual characteristics have been considered, ignoring the fact that individuals are influenced by their surroundings. One of the main contributions of this paper is to provide new evidence on the role that social networks play in determining various employment outcomes in Bolivia. We find evidence that social networks are an effective channel through which men and women obtain access to higher quality jobs (wage/salary work vis á vis self-employed). Furthermore, when we consider the sex of the contact we find that in urban areas men and women tend to use same sex contacts to find a job as 
a salaried worker. This finding suggests that social contacts have positive externality effects that can potentially increase the welfare of Bolivian workers, as these contacts are useful in finding better quality jobs.

The policy implications of these findings are threefold. First, the analysis of labor market discrimination should consider the effects of social networks on labor market outcomes. Not considering this variable may lead to interpreting several labor market outcomes such us labor market segregation and wage differentials as discrimination when these outcomes may in fact be the result, to some extent, of the mechanisms that men and women use to find a job.

Second, even though the percentage of women working as salaried workers impacts positively on the probability of women's obtaining a salaried job in urban areas, only 41.9 percent of women women actually have this type of job, compared to 59.4 percent of men. Affirmative action policies oriented to increase the participation of women in salaried jobs are therefore needed to improve the working conditions of women. Furthermore, such policies will have spillover effects, since they will benefit not only women who are appointed to those jobs but also women in their surroundings through the multiplier effect of the social network. In rural areas, however, women benefit more from the presence of male salaried workers. Consequently, the latter policy implications do not hold in rural areas.

Finally, social networks in Bolivia are used to find jobs as salary workers vis á vis selfemployment. Therefore, we can infer that networks are used by employers to eliminate part of the asymmetry of information they have about prospective employees and for future employees to obtain information about job openings. Policies oriented to reduce these asymmetries of information, such us state-run job agencies, might simplify and accelerate the job-search process.

In Bolivia, there is scarce evidence about the determinants of female labor force participation and the probability of obtaining a salaried job. In line with the international evidence, we find that marriage (urban sample) and having small children (rural sample) impact negatively on the probability of participating in the labor market. In contrast, there is weak evidence that marriage increases the probability that men participate in the labor market, as does having small children in the household. These results suggest that women bear the main responsibility for domestic and child care activities, while men are primarily responsible for market-oriented activities. Therefore, policies oriented to increase female labor force participation and/or the percentage of women who hold quality jobs need to be accompanied by 
measures that help women take care of the domestic activities within their home, such as day care services for small children.

The role of education is a robust result. Education is correlated with the probability to find a wage/salary job for both men and women, in urban and rural areas. This result highlights the importance of public policy programs oriented to increase the levels of education. This is particularly important for Bolivian women, who have much less education than their male counterparts. 


\section{References}

Altonji, J.G., and R.M. Blank. 1999. "Race and Gender in the Labor Market.” In: O. Ashenfelter and D. Card, editors. Handbook of Labor Economics. Volume 3C. Amsterdam, The Netherlands: North-Holland.

Arrow, K.J. 1998. “What Has Economics to Say About Racial Discrimination?” Journal of Economic Perspectives 12(2): 91-100.

Bayer, P., and S. Ross. 2006. "Identifying Individual and Group Effects in the Presence of Sorting: A Neighborhood Effects Application.” NBER Working Paper 12211. Cambridge, United States: National Bureau of Economic Research.

Bayer, P., S. Ross and G. Topa. 2004. "Place of Work and Place of Residence: Informal Hiring Networks and Labor Market Outcomes." Storrs, United States: University of Connecticut.

Beggs, J.J., and J.S. Hurlbert. 1997. “The Social Context of Men's and Women's Job Search Ties: Membership in Voluntary Organizations, Social Resources, and Job Search Outcomes.” Sociological Perspectives 40: 601-622.

Bernhardt, A., M. Morris, and M. Handcock. 1995. “Women’s Gains or Men’s Losses? A Closer Look at the Shrinking Gender Gap in Earnings.” American Journal of Sociology 101(2): 302-328.

Bertrand, M., L. Erzo and M. Sendhil. 2000. "Network Effects and Welfare Cultures.” Quarterly Journal of Economics 115(3): 1019-55.

Bramoullé, Y., H. Djebbari H., Fortin B. 2007. "Identification of Peer Effects through Social Networks.” IZA Discussion Paper 2652. Bonn, Germany: Institute for the Study of Labor (IZA).

Brass, D.J. 1985. “Men’s and Women’s Networks: A Study of Interaction Patterns and Influence in an Organization.” Academy of Management Journal 28: 327-343.

Bravo, D., C. Sanhueza and S. Urzúa. 2007. "Gender Discrimination and Economic Outcomes in Chile.” Research Network Working Paper R-541. Washington, DC, United States: InterAmerican Development Bank.

Bravo, R., and D. Zapata. 2005. Las metas del Milenio y la igualdad de género: El caso de Bolivia.” Serie Mujer y Desarrollo 71. Santiago, Chile: Comisión Económica para Latinoamérica y el Caribe, Unidad Mujer y Desarrollo. www.eclac.org/mujer. 
Calvó-Armengol, A. 2004. “Job Contact Networks.” Journal of Economic Theory 115(1): 191206.

Calvó-Armengol, A., and M.O. Jackson. 2004. "The Effects of Social Networks on Employment and Inequality.” American Economic Review 94(3): 426-454.

Calvó-Armengol, A., and M.O. Jackson. 2007. "Social Networks in Labor Markets: Wage and Employment Dynamics and Inequality.” Journal of Economic Theory 132(1): 27-46.

Case, A.C., and L.F. Katz. 1991. "The Company You Keep: The Effects of Family and Neighborhood on Disadvantaged Youths. NBER Working Paper 3705. Cambridge, United States: National Bureau of Economic Research.

Cattell, V. 2001. "Poor People, Poor Places, and Poor Health: The Mediating Role of Social Networks and Social Capital.” Social Science and Medicine 52: 1501-1516.

Conley, T., and G. Topa. 2002. "Socio-Economic Distance and Spatial Patterns in Unemployment.” Journal of Applied Econometrics 17(4): 303-327.

Contreras, D., Kruger, D.I., Zapata, D. 2006. “Economic Opportunities for Indigenous People in Bolivia.” Background report for: Economic Opportunities for Indigenous Peoples in Latin America. Washington, DC, United States: World Bank. http://siteresources.worldbank.org/EDUCATION/Resources/278200-1169235401815/Bolivia.pdf.

Elliott, J.R. 1999. "Social Isolation and Labor Market Insulation: Network and Neighborhood Effects on Less-Educated Urban Workers.” Sociological Quarterly 40(2): 199-216.

Gasparini, L., and L. Tornarolli. 2007. "Labor Informality in Latin America and the Caribbean: Patterns and Trends from Household Survey Microdata.” Working Paper 46. Universidad Nacional de La Plata: Centro de Estudios Distributivos, Laborales y Sociales.

Gaviria, A., and S. Raphael. 2001. "School-Based Peer Effects and Juvenile Behavior.” Review of Economics and Statistics 83(2): 257-268.

Granovetter, M. 1973. “The Strength of Weak Ties.” American Journal of Sociology 78: 13601380.

Granovetter, M. 1995. Getting a Job: A Study of Contacts and Careers. Chicago, United States: University of Chicago Press.

Hanson, S., and G. Pratt. 1991. "Job Search and the Occupational Segregation of Women." Annals of the Association of American Geographers 81: 229-253. 
Hirsh B. et al. 1990. "The Role of Social Environments in Social Support.” In: B. Sarason, I. Sarason and G. Pierce, editors. Social Support: An Interactional View. Washington, United States: Wiley.

Inter-American Development Bank. 2003. Se buscan buenos empleos: Los mercados laborales en América Latina. Informe de progreso ecónomico y social. Washington, DC, United Status: Inter-American Development Bank.

Ioannides, Y., and L.D. Loury. 2004. "Job Information Networks, Neighborhood Effects, and Inequality.” Journal of Economic Literature 42(4): 1056-1093.

Jackson, M. 2003. “A Survey of Models of Network Formation: Stability and Efficiency.” In: G. Demange and M. Wooders, editors. Group Formation in Economics: Networks, Clubs, and Coalitions. Cambridge, United Kingdom: Cambridge University Press.

Krauth, B. 2004. "Maximum Likelihood Estimation of Social Interaction Effects with Nonrandom Group Selection.” Burnaby, Canada: Simon Fraser University, Department of Economics. Mimeographed document.

Krauth, B. 2006. "Simulation-Based Estimation of Peer Effects." Journal of Econometrics 133(1): 243-271.

Manski, C. 1993. "Identification of Endogenous Social Effects: The Reflection Problem." Review of Economic Studies 60(3): 531-542.

Manski, C. 1999. Identification Problems in Social Sciences. Cambridge, United States: Harvard University Press. bridge, MA.

McPherson, M., and L. Smith-Lovin. 1982. "Women and Weak Ties: Differences by Sex and Size of Voluntary Organizations.” American Journal of Sociology 87: 883-904.

McPherson, M., and L. Smith-Lovin. 1986. "Sex Segregation in Voluntary Associations." American Sociological Review 51, 61-79.

Mencken, F.C., and I. Winfield. 2000. "Job Search and Sex Segregation: Does Sex of Social Contact Matter?” Sex Roles 42(9-10): 847-864.

Moffitt, R.A. 2001. "Policy Interventions, Low-Level Equilibria, and Social Interactions.” In: S. Durlauf and H. Young, editors. Social Dynamics. Cambridge, United States: MIT Press.

Montgomery, J. 1991. "Social Networks and Labor Market Outcomes: Towards an Eonomic Analysis.” American Economic Review 81(5): 1408-1418. 
Moreno, M., H. Ñopo, J. Saavedra and M. Torero. 2004. “Gender and Racial Discrimination in Hiring: A Pseudo Audit Study for Three Selected Occupations in Metropolitan Lima.” IZA Discussion Paper 979. Bonn, Germany: Institute for the Study of Labor (IZA).

Ñopo, H. 2004. “Matching as a Tool to Decompose Wage Gaps.” IZA Discussion Paper 981. Bonn Germany, Institute for the Study of Labor (IZA).

Ñopo, H. 2007. “The Gender Wage Gap in Chile 1992-2003 from a Matching Comparisons Perspective.” IZA Discussion Paper 2698. Bonn Germany, Institute for the Study of Labor (IZA).

Núñez, J., and R. Gutiérrez, R. 2004. "Class Discrimination and Meritocracy in the Labor Market: The Case of Chile.” Estudios de Economía 31(2): 113-132.

Petersen, T., I. Saporta, and M.D. Seidel. 2000. “Offering a Job: Meritocracy and Social Networks.” American Journal of Sociology 106(3): 763-816.

Rees, A. 1966. “Information Networks in Labor Markets.” American Economic Review 56: 559566.

Sacerdote, B. 2001. "Peer Effects with Random Assignment: Results for Dartmouth Roommates.” Quarterly Journal of Economics 116(2): 681-703.

Scheinkman, J. Forthcoming 2008. “Theory of Social Interactions.” In: S.N. Durlauf and L.E. Blume, editors. The New Palgrave Dictionary of Economics. Second edition. Hampshire, United Kingdom: Palgrave Macmillan.

Soetevent, A. 2006. "Empirics of the Identification of Social Interactions: An Evaluation of the Approaches and Their Results.” Journal of Economic Surveys 20(2): 193-228.

Straits, B. 1998. “Occupational Sex Segregation: The Role of Personal Ties.” Journal of Vocational Behavior 52: 191-207.

Topa, G. 2001. “Social Interactions, Local Spillovers and Unemployment.” Review of Economic Studies 68(2): 261-95.

Van Ham, M., and F. Buchel. 2006. ”Unwilling or unable? Spatial and Socio-Economic Restrictions on Female’s Labour Market Access.” Regional Studies 40(3): 345-357.

Wahba, J., and Y. Zenou. 2005. "Density, Social Networks and Job Search Methods: Theory and Application to Egypt.” Journal of Development Economics 78(2): 443-473.

Weinberg, B., P.B. Reagan and J.J. Yankow. 2004. "Do Neighborhoods Affect Hours Worked? Evidence from Longitudinal Data.” Journal of Labor Economics 22(4): 891-924. 
World Bank. 2006. World Development Indicators Database. Washington, DC, United States: World Bank. 
Table 1. Employment Characteristics by Gender, 2001 (25-60 years old)

\begin{tabular}{lccc}
\hline \hline & Men & Women & Total \\
\hline Labor force participation rate (\%) & & & \\
$\quad$ Urban & 94.7 & 73.3 & 83.4 \\
Rural & 98.9 & 78.4 & 88.6 \\
Total & 96.2 & 75.0 & 85.2 \\
Employed (\%) & & & \\
$\quad$ Urban & 92.4 & 89.7 & 91.2 \\
Rural & 99.4 & 98.6 & 99.1 \\
Total & 95.6 & 93.5 & 94.7 \\
UNPAID WORKERS (\%) & & & \\
Urban & 11.0 & 18.1 & 14.2 \\
Rural & 35.3 & 72.3 & 51.6 \\
Total & 22.3 & 42.8 & 31.4 \\
PAID WORKERS & & & \\
Wage workers (\%) (1) & & & \\
$\quad$ Urban & 59.4 & 41.9 & 51.8 \\
$\quad$ Rural & 18.5 & 20.7 & 19.1 \\
$\quad$ Total & 44.1 & 37.8 & 41.7 \\
Self-employment (\%) (1) & & & \\
$\quad$ Urban & 35.4 & 55.1 & 44.0 \\
$\quad$ Rural & 79.0 & 77.0 & 78.5 \\
$\quad$ Total & 51.8 & 59.4 & 54.6 \\
Works as an Employer (\%) (1) & & & \\
$\quad$ Urban & 5.2 & 3.0 & 4.2 \\
$\quad$ Rural & 2.5 & 2.3 & 2.4 \\
$\quad$ Total & 4.1 & 2.8 & 3.7 \\
\hline \hline
\end{tabular}

Source: Authors' calculations based on MECOVI 2001.

(1) As a percentage of paid workers. 
Table 2. Selected Individual Characteristics by Gender (25-60 years old)

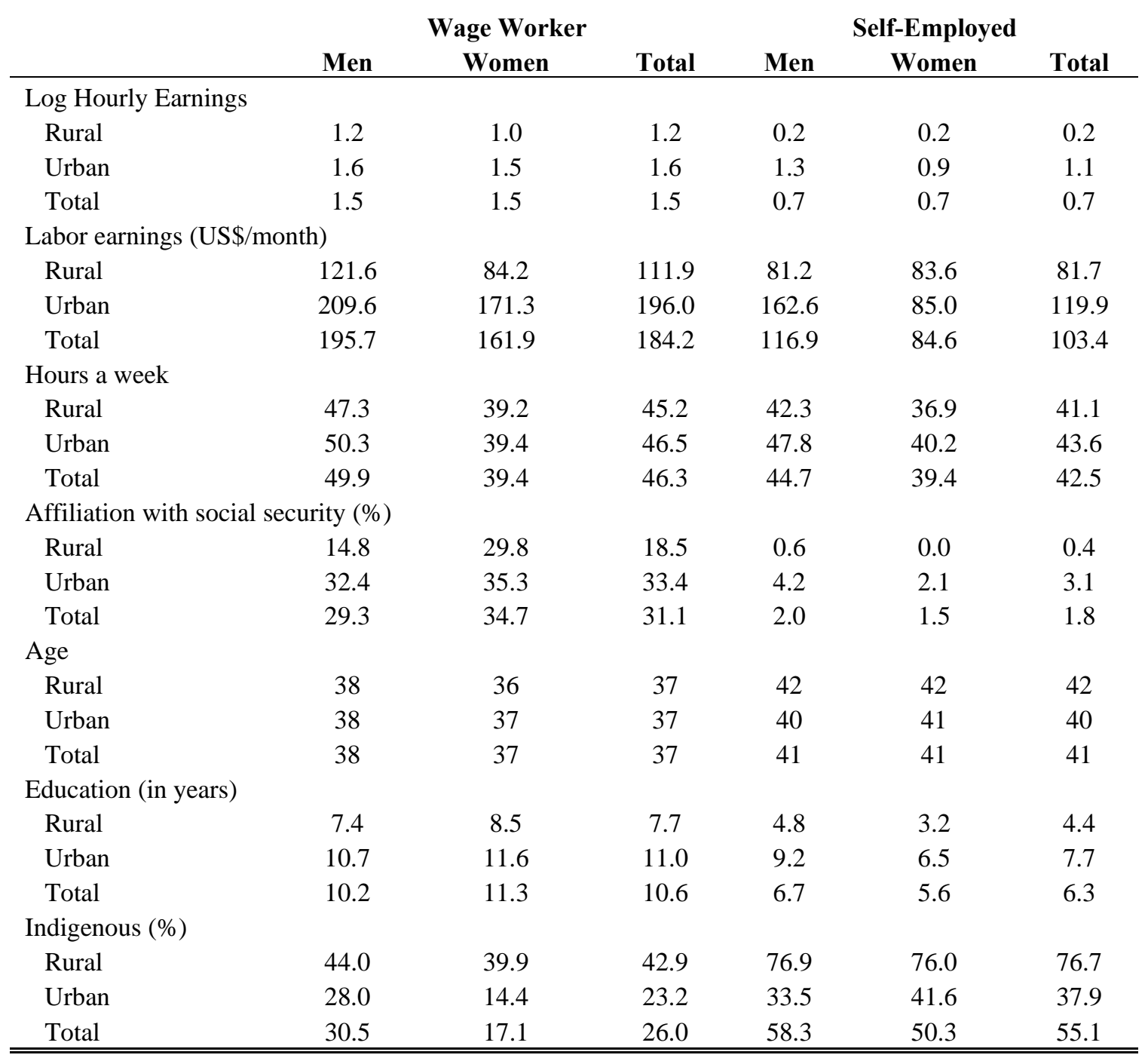

Source: Authors' calculations based on MECOVI 2001.

Note: Standard error in parentheses. 
Table 3. Selected Neighborhood Characteristics

\begin{tabular}{|c|c|c|c|c|c|c|}
\hline & \multicolumn{2}{|c|}{ Urban } & \multicolumn{2}{|c|}{ Rural } & \multicolumn{2}{|c|}{ Total } \\
\hline & Mean & $\begin{array}{l}\text { Standard } \\
\text { deviation }\end{array}$ & Mean & $\begin{array}{l}\text { Standard } \\
\text { deviation }\end{array}$ & Mean & $\begin{array}{l}\text { Standard } \\
\text { deviation }\end{array}$ \\
\hline Percent-indigenous & 0.28 & 0.22 & 0.67 & 0.37 & 0.40 & 0.33 \\
\hline Percent-poverty & 0.45 & 0.35 & 0.90 & 0.17 & 0.59 & 0.37 \\
\hline $\begin{array}{l}\text { Average number of children under } 6 \\
\text { years of age in the household }\end{array}$ & 0.83 & 0.23 & 1.09 & 0.43 & 0.91 & 0.33 \\
\hline $\begin{array}{l}\text { Average number of children aged } 6 \text { to } \\
18 \text { in the household }\end{array}$ & 1.76 & 0.39 & 1.95 & 0.64 & 1.82 & 0.49 \\
\hline Average employed workers & 0.67 & 0.05 & 0.67 & 0.20 & 0.67 & 0.12 \\
\hline Average employed female workers & 0.54 & 0.07 & 0.47 & 0.30 & 0.51 & 0.18 \\
\hline Average employed male workers & 0.81 & 0.04 & 0.86 & 0.17 & 0.83 & 0.10 \\
\hline Average wage/salary workers & 0.33 & 0.07 & 0.12 & 0.12 & 0.26 & 0.13 \\
\hline Average female wage/salary workers & 0.23 & 0.10 & 0.06 & 0.09 & 0.18 & 0.12 \\
\hline Average male wage/salary workers & 0.44 & 0.06 & 0.18 & 0.18 & 0.36 & 0.17 \\
\hline Population 25 to 60 years old & 1301 & 323 & 163 & 208 & 854 & 624 \\
\hline
\end{tabular}

Source: Authors' calculations based on 2001 Census. 
Table 4. Summary of the effect of social networks on the probability of working as a wage/salary worker

(change in the probability for a change in the social network variable)

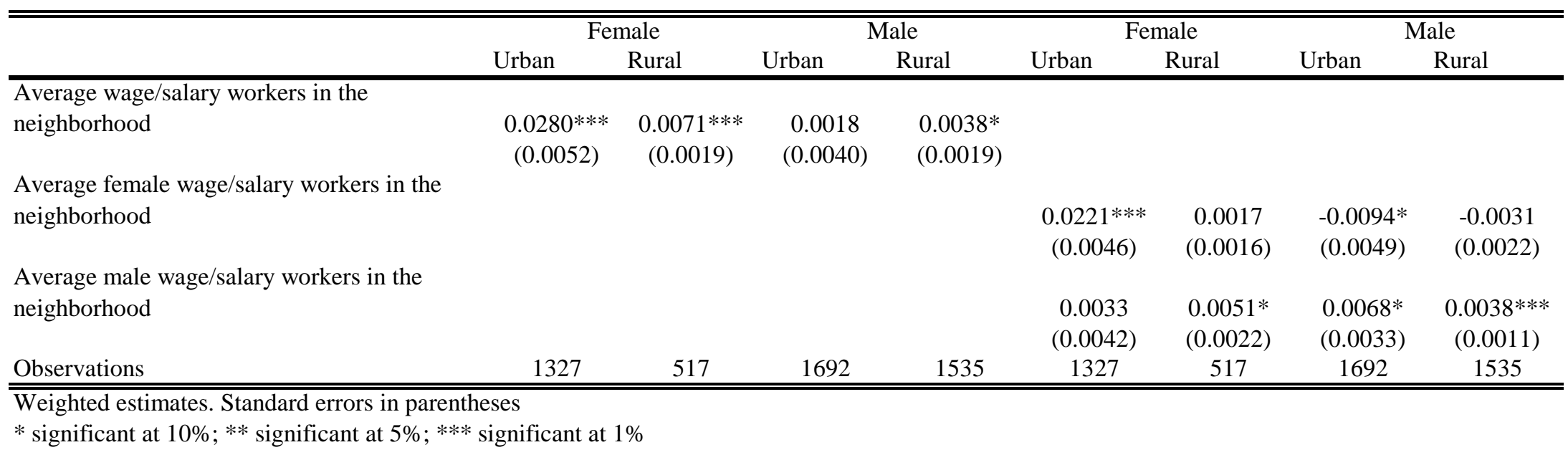


Table 5. Labor Market Outcomes Regressions, Female Urban Sample

\begin{tabular}{|c|c|c|c|c|c|c|c|c|}
\hline \multirow[t]{3}{*}{ Dependent variable: } & \multicolumn{4}{|c|}{ Labor force participation } & \multicolumn{4}{|c|}{ Wage work } \\
\hline & (1) & $(2)$ & (3) & (4) & (5) & (6) & $(7)$ & $(8)$ \\
\hline & $F E$ & $I V$ & $F E$ & $I V$ & $F E$ & $I V$ & $F E$ & $I V$ \\
\hline $\begin{array}{l}\text { Average employment in the } \\
\text { neighborhood }\end{array}$ & $\begin{array}{c}0.0012 \\
(0.0029)\end{array}$ & $\begin{array}{c}0.0205 \\
(0.0223)\end{array}$ & & & & & & \\
\hline $\begin{array}{l}\text { Average female employment in } \\
\text { the neighborhood }\end{array}$ & & & $\begin{array}{c}0.0040 \\
(0.0024)\end{array}$ & $\begin{array}{c}0.0769 \\
(0.0524)\end{array}$ & & & & \\
\hline $\begin{array}{l}\text { Average male employment in } \\
\text { the neighborhood }\end{array}$ & & & $\begin{array}{l}-0.0052 \\
(0.0042)\end{array}$ & $\begin{array}{l}-0.0640 \\
(0.0580)\end{array}$ & & & & \\
\hline $\begin{array}{l}\text { Average wage/salary workers i } \\
\text { the neighborhood }\end{array}$ & & & & & $\begin{array}{c}0.0280 * * * \\
(0.0052)\end{array}$ & $\begin{array}{l}0.0631^{* *} \\
(0.0320)\end{array}$ & & \\
\hline $\begin{array}{l}\text { Average male wage/salary } \\
\text { workers in the neighborhood }\end{array}$ & & & & & & & $\begin{array}{l}0.0033 \\
(0.0042)\end{array}$ & $\begin{array}{l}-0.0078 \\
(0.0293)\end{array}$ \\
\hline Percent-indigenous & $\begin{array}{c}0.0007 \\
(0.0008)\end{array}$ & $\begin{array}{l}-0.0009 \\
(0.0054)\end{array}$ & $\begin{array}{c}0.0003 \\
(0.0009)\end{array}$ & $\begin{array}{l}-0.0040 \\
(0.0064)\end{array}$ & $\begin{array}{c}0.0003 \\
(0.0019)\end{array}$ & $\begin{array}{l}-0.0132 \\
(0.0128)\end{array}$ & $\begin{array}{l}0.0028 * \\
(0.0017)\end{array}$ & $\begin{array}{l}-0.0073 \\
(0.0120)\end{array}$ \\
\hline Percent-poverty & $\begin{array}{c}-0.0018 * * \\
(0.0008)\end{array}$ & $\begin{array}{l}-0.0085^{*} \\
(0.0044)\end{array}$ & $\begin{array}{l}-0.0016 * \\
(0.0009)\end{array}$ & $\begin{array}{l}-0.0112 * * \\
(0.0051)\end{array}$ & $\begin{array}{l}-0.0004 \\
(0.0012)\end{array}$ & $\begin{array}{l}-0.0047 \\
(0.0067)\end{array}$ & $\begin{array}{l}0.0002 \\
(0.0013)\end{array}$ & $\begin{array}{l}0.0002 \\
(0.0083)\end{array}$ \\
\hline $\begin{array}{l}\text { Share of people with high- } \\
\text { school education or more }\end{array}$ & $\begin{array}{c}-0.0034^{* *} \\
(0.0015)\end{array}$ & $\begin{array}{c}0.0049 \\
(0.0060)\end{array}$ & $\begin{array}{c}-0.0040 * * \\
(0.0016)\end{array}$ & $\begin{array}{l}-0.0043 \\
(0.0084)\end{array}$ & $\begin{array}{c}-0.0060 * * \\
(0.0025)\end{array}$ & $\begin{array}{l}-0.0087 \\
(0.0133)\end{array}$ & $\begin{array}{l}-0.0051 * \\
(0.0027)\end{array}$ & $\begin{array}{l}-0.0252 * \\
(0.0144)\end{array}$ \\
\hline Household head & $\begin{array}{c}0.0849 * * * \\
(0.0291)\end{array}$ & $\begin{array}{c}0.1159 * * * \\
(0.0327)\end{array}$ & $\begin{array}{c}0.0838 * * * \\
(0.0291)\end{array}$ & $\begin{array}{c}0.1078 * * * \\
(0.0398)\end{array}$ & $\begin{array}{l}-0.0313 \\
(0.0605)\end{array}$ & $\begin{array}{l}-0.0471 \\
(0.0782)\end{array}$ & $\begin{array}{l}-0.0342 \\
(0.0592)\end{array}$ & $\begin{array}{l}-0.0315 \\
(0.0783)\end{array}$ \\
\hline Age2 & $\begin{array}{c}-0.0000 * * * \\
(0.0000)\end{array}$ & $\begin{array}{c}-0.0008 * * * \\
(0.0002)\end{array}$ & $\begin{array}{c}-0.0000 * * * \\
(0.0000)\end{array}$ & $\begin{array}{c}-0.0008 * * * \\
(0.0002)\end{array}$ & $\begin{array}{c}0.0000 \\
(0.0000)\end{array}$ & $\begin{array}{c}0.0001 \\
(0.0003)\end{array}$ & $\begin{array}{l}0.0000 \\
(0.0000)\end{array}$ & $\begin{array}{l}0.0001 \\
(0.0003)\end{array}$ \\
\hline Education & $\begin{array}{c}0.0081^{* * *} \\
(0.0027)\end{array}$ & $\begin{array}{l}0.0149 * \\
(0.0082)\end{array}$ & $\begin{array}{c}0.0079 * * * \\
(0.0027)\end{array}$ & $\begin{array}{c}0.0031 \\
(0.0158)\end{array}$ & $\begin{array}{c}0.0387 * * * \\
(0.0045)\end{array}$ & $\begin{array}{c}0.0131 \\
(0.0148)\end{array}$ & $\begin{array}{l}0.0387 * * * \\
(0.0044)\end{array}$ & $\begin{array}{l}0.0166 \\
(0.0149)\end{array}$ \\
\hline Married & $\begin{array}{c}-0.1110 * * * \\
(0.0254)\end{array}$ & $\begin{array}{c}-0.0850 * * \\
(0.0338)\end{array}$ & $\begin{array}{c}-0.1123^{* * *} \\
(0.0253)\end{array}$ & $\begin{array}{c}-0.1031^{* *} \\
(0.0406)\end{array}$ & $\begin{array}{c}-0.2005^{* * *} \\
(0.0590)\end{array}$ & $\begin{array}{c}-0.2305^{* * *} \\
(0.0799)\end{array}$ & $\begin{array}{l}-0.1881^{* * *} \\
(0.0582)\end{array}$ & $\begin{array}{l}-0.2006 * * \\
(0.0824)\end{array}$ \\
\hline Indigenous & $\begin{array}{c}0.0488 \\
(0.0338)\end{array}$ & $\begin{array}{l}-0.0031 \\
(0.1181)\end{array}$ & $\begin{array}{c}0.0492 \\
(0.0335)\end{array}$ & $\begin{array}{c}0.0123 \\
(0.1321)\end{array}$ & $\begin{array}{l}-0.0299 \\
(0.0521)\end{array}$ & $\begin{array}{c}0.5063^{* * *} \\
(0.1896)\end{array}$ & $\begin{array}{l}-0.0311 \\
(0.0504)\end{array}$ & $\begin{array}{l}0.5027^{* * *} \\
(0.1923)\end{array}$ \\
\hline $\begin{array}{l}\text { HH members under } 6 \text { years of } \\
\text { age }\end{array}$ & $\begin{array}{l}-0.0101 \\
(0.0120)\end{array}$ & $\begin{array}{l}-0.0265 \\
(0.0168)\end{array}$ & $\begin{array}{l}-0.0095 \\
(0.0118)\end{array}$ & $\begin{array}{l}-0.0038 \\
(0.0292)\end{array}$ & $\begin{array}{l}-0.0329 * \\
(0.0197)\end{array}$ & $\begin{array}{c}0.0156 \\
(0.0353)\end{array}$ & $\begin{array}{l}-0.0354 * \\
(0.0199)\end{array}$ & $\begin{array}{l}-0.0104 \\
(0.0394)\end{array}$ \\
\hline $\begin{array}{l}\text { HH members aged between } 6 \mathrm{t} \\
18\end{array}$ & $\begin{array}{l}-0.0135 \\
(0.0088)\end{array}$ & $\begin{array}{l}-0.0206 \\
(0.0139)\end{array}$ & $\begin{array}{l}-0.0131 \\
(0.0088)\end{array}$ & $\begin{array}{c}0.0032 \\
(0.0276)\end{array}$ & $\begin{array}{c}0.0120 \\
(0.0151)\end{array}$ & $\begin{array}{c}0.0350 \\
(0.0305)\end{array}$ & $\begin{array}{l}0.0171 \\
(0.0151)\end{array}$ & $\begin{array}{l}0.0303 \\
(0.0317)\end{array}$ \\
\hline $\begin{array}{l}\text { HH members } 60 \text { years old or } \\
\text { older }\end{array}$ & $\begin{array}{c}0.0061 \\
(0.0256)\end{array}$ & $\begin{array}{c}0.0139 \\
(0.0289)\end{array}$ & $\begin{array}{c}0.0048 \\
(0.0255)\end{array}$ & $\begin{array}{c}0.0021 \\
(0.0346)\end{array}$ & $\begin{array}{c}0.0231 \\
(0.0427)\end{array}$ & $\begin{array}{c}0.0099 \\
(0.0631)\end{array}$ & $\begin{array}{l}0.0360 \\
(0.0430)\end{array}$ & $\begin{array}{l}-0.0461 \\
(0.0746)\end{array}$ \\
\hline Observations & 2299 & 2299 & 2299 & 2299 & 1327 & 1327 & 1327 & 1327 \\
\hline
\end{tabular}

Results express marginal probabilities. Weighted estimates. Robust standard errors in parentheses. * significant at $10 \%$; ** significant at $5 \%$; *** significant at $1 \%$ Not shown: Municipality fixed effects. 


\section{Table 6. Labor Market Outcomes Regressions,}

Female Rural Sample

\begin{tabular}{|c|c|c|c|c|}
\hline \multirow[t]{3}{*}{ Dependent variable: } & \multicolumn{2}{|c|}{ Labor force participation } & \multicolumn{2}{|c|}{ Wage work } \\
\hline & (1) & (2) & (3) & (4) \\
\hline & $F E$ & $F E$ & $F E$ & $F E$ \\
\hline Average employment in the neighborhood & $\begin{array}{c}0.0011 \\
(0.0011)\end{array}$ & & & \\
\hline $\begin{array}{l}\text { Average female employment in the } \\
\text { neighborhood }\end{array}$ & & $\begin{array}{c}0.0011 \\
(0.0008)\end{array}$ & & \\
\hline $\begin{array}{l}\text { Average male employment in the } \\
\text { neighborhood }\end{array}$ & & $\begin{array}{l}-0.0004 \\
(0.0014)\end{array}$ & & \\
\hline $\begin{array}{l}\text { Average wage/salary workers in the } \\
\text { neighborhood }\end{array}$ & & & $\begin{array}{l}0.0071 * * * \\
(0.0019)\end{array}$ & \\
\hline $\begin{array}{l}\text { Average female wage/salary workers in } \\
\text { the neighborhood }\end{array}$ & & & & $\begin{array}{l}0.0017 \\
(0.0016)\end{array}$ \\
\hline $\begin{array}{l}\text { Average male wage/salary workers in the } \\
\text { neighborhood }\end{array}$ & & & & $\begin{array}{l}0.0051^{* *} \\
(0.0022)\end{array}$ \\
\hline Percent-indigenous & $\begin{array}{c}0.0019^{* * *} \\
(0.0005)\end{array}$ & $\begin{array}{c}0.0017^{* * *} \\
(0.0005)\end{array}$ & $\begin{array}{c}-0.0024^{* * *} \\
(0.0006)\end{array}$ & $\begin{array}{l}-0.0022 * * * \\
(0.0006)\end{array}$ \\
\hline Percent-poverty & $\begin{array}{c}0.0006 \\
(0.0010)\end{array}$ & $\begin{array}{c}0.0007 \\
(0.0010)\end{array}$ & $\begin{array}{c}0.0011 \\
(0.0016)\end{array}$ & $\begin{array}{l}0.0011 \\
(0.0014)\end{array}$ \\
\hline $\begin{array}{l}\text { Share of people with high-school } \\
\text { education or more }\end{array}$ & $\begin{array}{l}-0.0005 \\
(0.0016)\end{array}$ & $\begin{array}{l}-0.0005 \\
(0.0016)\end{array}$ & $\begin{array}{l}-0.0035 \\
(0.0027)\end{array}$ & $\begin{array}{l}-0.0036 \\
(0.0029)\end{array}$ \\
\hline Household head & $\begin{array}{l}0.1480 * * * \\
(0.0254)\end{array}$ & $\begin{array}{c}0.1488^{* * * *} \\
(0.0256)\end{array}$ & $\begin{array}{l}-0.0244 \\
(0.0606)\end{array}$ & $\begin{array}{l}-0.0193 \\
(0.0585)\end{array}$ \\
\hline Age & $\begin{array}{l}0.0272 * * \\
(0.0116)\end{array}$ & $\begin{array}{l}0.0275^{* *} \\
(0.0116)\end{array}$ & $\begin{array}{l}-0.0090 \\
(0.0196)\end{array}$ & $\begin{array}{l}-0.0071 \\
(0.0194)\end{array}$ \\
\hline Age2 & $\begin{array}{l}-0.0000^{* *} \\
(0.0000)\end{array}$ & $\begin{array}{l}-0.0000^{* *} \\
(0.0000)\end{array}$ & $\begin{array}{c}0.0000 \\
(0.0000)\end{array}$ & $\begin{array}{l}0.0000 \\
(0.0000)\end{array}$ \\
\hline Education & $\begin{array}{c}0.0061 \\
(0.0037)\end{array}$ & $\begin{array}{c}0.0056 \\
(0.0039)\end{array}$ & $\begin{array}{c}0.0283^{* * *} \\
(0.0058)\end{array}$ & $\begin{array}{l}0.0275^{* * *} \\
(0.0055)\end{array}$ \\
\hline Married & $\begin{array}{l}-0.0253 \\
(0.0368)\end{array}$ & $\begin{array}{l}-0.0218 \\
(0.0364)\end{array}$ & $\begin{array}{c}0.0166 \\
(0.0518)\end{array}$ & $\begin{array}{l}0.0215 \\
(0.0511)\end{array}$ \\
\hline Indigenous & $\begin{array}{c}0.0517 \\
(0.0411)\end{array}$ & $\begin{array}{c}0.0456 \\
(0.0404)\end{array}$ & $\begin{array}{c}-0.0028 \\
(0.0571)\end{array}$ & $\begin{array}{l}-0.0072 \\
(0.0569)\end{array}$ \\
\hline HH members under 6 years of age & $\begin{array}{c}-0.0246 * \\
(0.0141)\end{array}$ & $\begin{array}{c}-0.0244^{*} \\
(0.0139)\end{array}$ & $\begin{array}{c}0.0074 \\
(0.0242)\end{array}$ & $\begin{array}{l}0.0047 \\
(0.0247)\end{array}$ \\
\hline HH members aged between 6 to 18 & $\begin{array}{c}-0.0047 \\
(0.0084)\end{array}$ & $\begin{array}{c}-0.0049 \\
(0.0084)\end{array}$ & $\begin{array}{c}-0.0232 * \\
(0.0130)\end{array}$ & $\begin{array}{l}-0.0228^{*} \\
(0.0128)\end{array}$ \\
\hline HH members 60 years old or older & $\begin{array}{c}0.0356 \\
(0.0394)\end{array}$ & $\begin{array}{c}0.0325 \\
(0.0386)\end{array}$ & $\begin{array}{c}-0.0843^{*} \\
(0.0463)\end{array}$ & $\begin{array}{l}-0.0834 * \\
(0.0441)\end{array}$ \\
\hline Observations & 1679 & 1679 & 517 & 517 \\
\hline
\end{tabular}

Results express marginal probabilities. Weighted estimates. Robust standard errors in parentheses.

* significant at $10 \%$; ** significant at $5 \%$; *** significant at $1 \%$. Not shown: Municipality fixed effects. 
Table 7. Labor Market Outcomes Regressions,

Male Urban Sample

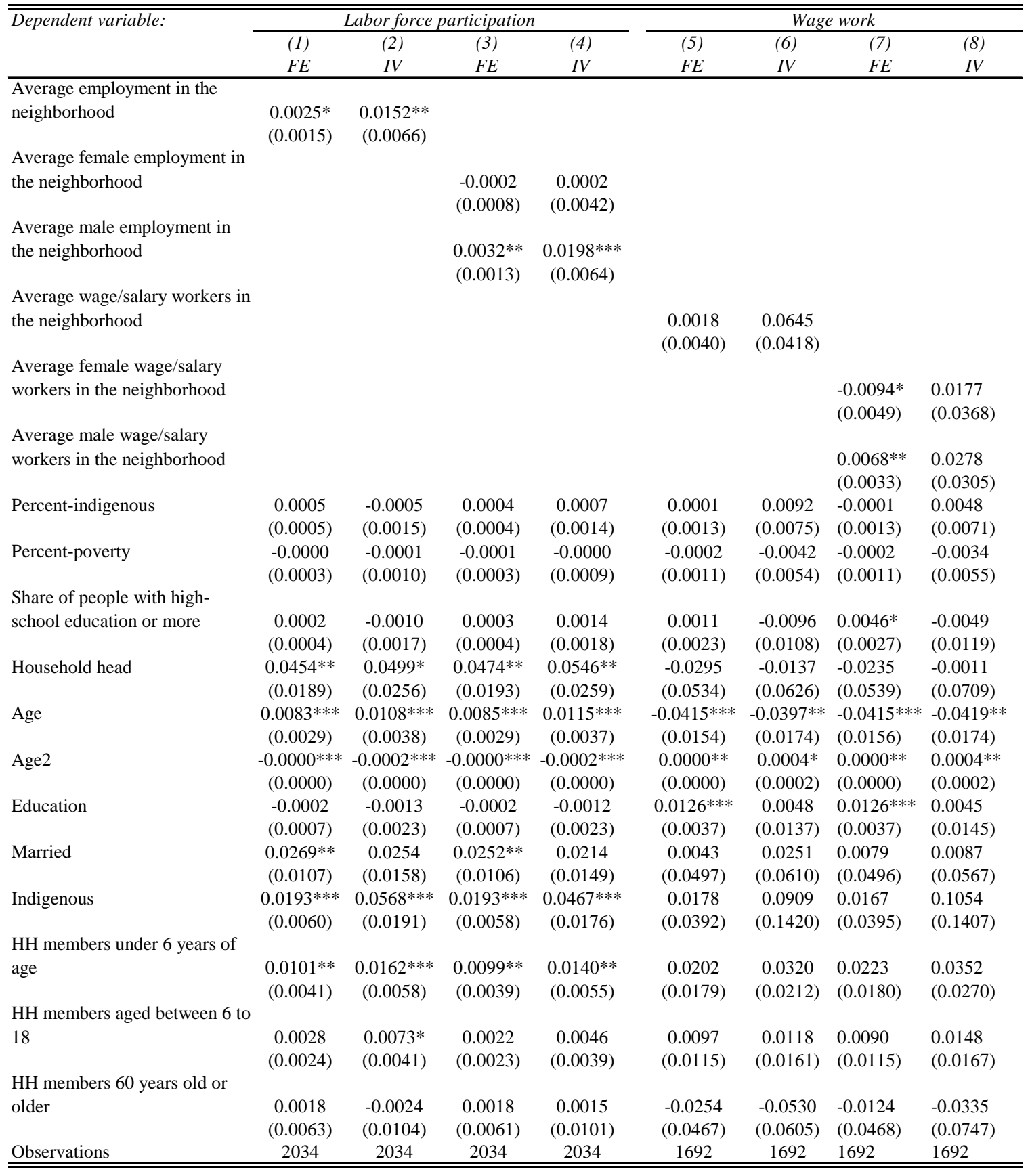

Results express marginal probabilities. Weighted estimates. Robust standard errors in parentheses. * significant at $10 \%$; $* *$ significant at $5 \%$; *** significant at $1 \%$ Not shown: Municipality fixed effects. 


\section{Table 8. Labor Market Outcomes Regressions,}

Male Rural Sample

\begin{tabular}{|c|c|c|c|c|}
\hline \multirow[t]{3}{*}{ Dependent variable: } & \multicolumn{2}{|c|}{ Labor force participation } & \multicolumn{2}{|c|}{ Wage work } \\
\hline & (1) & (2) & (3) & (4) \\
\hline & $F E$ & $F E$ & $F E$ & $F E$ \\
\hline Average employment in the neighborhood & $\begin{array}{c}-0.0000 \\
(0.0000)\end{array}$ & & & \\
\hline $\begin{array}{l}\text { Average female employment in the } \\
\text { neighborhood }\end{array}$ & & $\begin{array}{l}-0.0000 \\
(0.0000)\end{array}$ & & \\
\hline $\begin{array}{l}\text { Average male employment in the } \\
\text { neighborhood }\end{array}$ & & $\begin{array}{c}0.0000 \\
(0.0000)\end{array}$ & & \\
\hline $\begin{array}{l}\text { Average wage/salary workers in the } \\
\text { neighborhood }\end{array}$ & & & $\begin{array}{l}0.0038 * \\
(0.0019)\end{array}$ & \\
\hline $\begin{array}{l}\text { Average female wage/salary workers in } \\
\text { the neighborhood }\end{array}$ & & & & $\begin{array}{l}-0.0031 \\
(0.0022)\end{array}$ \\
\hline $\begin{array}{l}\text { Average male wage/salary workers in the } \\
\text { neighborhood }\end{array}$ & & & & $\begin{array}{l}0.0038^{* * *} \\
(0.0011)\end{array}$ \\
\hline Percent-indigenous & $\begin{array}{l}-0.0000 \\
(0.0000)\end{array}$ & $\begin{array}{l}-0.0000 \\
(0.0000)\end{array}$ & $\begin{array}{l}-0.0011^{*} \\
(0.0006)\end{array}$ & $\begin{array}{l}-0.0009 * \\
(0.0006)\end{array}$ \\
\hline Percent-poverty & $\begin{array}{c}0.0000 \\
(0.0000)\end{array}$ & $\begin{array}{c}0.0000 \\
(0.0000)\end{array}$ & $\begin{array}{l}-0.0013 \\
(0.0010)\end{array}$ & $\begin{array}{l}-0.0014 \\
(0.0010)\end{array}$ \\
\hline $\begin{array}{l}\text { Share of people with high-school } \\
\text { education or more }\end{array}$ & $\begin{array}{c}-0.0000 \\
(0.0000)\end{array}$ & $\begin{array}{l}-0.0000 \\
(0.0000)\end{array}$ & $\begin{array}{c}-0.0002 \\
(0.0014)\end{array}$ & $\begin{array}{l}0.0004 \\
(0.0008)\end{array}$ \\
\hline Household head & $\begin{array}{c}0.0002 \\
(0.0004)\end{array}$ & $\begin{array}{c}0.0000 \\
(0.0001)\end{array}$ & $\begin{array}{l}-0.1158^{*} \\
(0.0681)\end{array}$ & $\begin{array}{l}-0.0974 \\
(0.0692)\end{array}$ \\
\hline Age & $\begin{array}{c}0.0000 \\
(0.0000)\end{array}$ & $\begin{array}{c}0.0000 \\
(0.0000)\end{array}$ & $\begin{array}{l}-0.0060 \\
(0.0099)\end{array}$ & $\begin{array}{l}-0.0052 \\
(0.0101)\end{array}$ \\
\hline Age2 & $\begin{array}{l}-0.0000 \\
(0.0000)\end{array}$ & $\begin{array}{l}-0.0000 \\
(0.0000)\end{array}$ & $\begin{array}{c}0.0000 \\
(0.0000)\end{array}$ & $\begin{array}{l}0.0000 \\
(0.0000)\end{array}$ \\
\hline Education & $\begin{array}{l}-0.0000 \\
(0.0000)\end{array}$ & $\begin{array}{l}-0.0000 \\
(0.0000)\end{array}$ & $\begin{array}{l}0.0193 * * * \\
(0.0034)\end{array}$ & $\begin{array}{l}0.0194 * * * \\
(0.0035)\end{array}$ \\
\hline Married & $\begin{array}{l}-0.0000 \\
(0.0000)\end{array}$ & $\begin{array}{l}-0.0000 \\
(0.0000)\end{array}$ & $\begin{array}{l}-0.1225^{* *} \\
(0.0526)\end{array}$ & $\begin{array}{l}-0.1239 * * \\
(0.0541)\end{array}$ \\
\hline Indigenous & $\begin{array}{c}0.0001 \\
(0.0001)\end{array}$ & $\begin{array}{c}0.0000 \\
(0.0000)\end{array}$ & $\begin{array}{l}-0.0488 \\
(0.0436)\end{array}$ & $\begin{array}{l}-0.0525 \\
(0.0443)\end{array}$ \\
\hline HH members under 6 years of age & $\begin{array}{l}-0.0000 \\
(0.0000)\end{array}$ & $\begin{array}{l}-0.0000 \\
(0.0000)\end{array}$ & $\begin{array}{c}0.0016 \\
(0.0111)\end{array}$ & $\begin{array}{l}0.0028 \\
(0.0111)\end{array}$ \\
\hline HH members aged between 6 to 18 & $\begin{array}{c}0.0000 \\
(0.0000)\end{array}$ & $\begin{array}{c}0.0000 \\
(0.0000)\end{array}$ & $\begin{array}{c}-0.0100 \\
(0.0084)\end{array}$ & $\begin{array}{l}-0.0097 \\
(0.0085)\end{array}$ \\
\hline HH members 60 years old or older & $\begin{array}{c}-0.0001 \\
(0.0001)\end{array}$ & $\begin{array}{c}-0.0000 \\
(0.0000)\end{array}$ & $\begin{array}{c}-0.0619 \\
(0.0464)\end{array}$ & $\begin{array}{l}-0.0677 \\
(0.0471)\end{array}$ \\
\hline Observations & 1681 & 1681 & 1535 & 1535 \\
\hline
\end{tabular}

Results express marginal probabilities. Weighted estimates. Robust standard errors in parentheses.

* significant at 10\%; ** significant at 5\%; *** significant at $1 \%$. Not shown: Municipality fixed effects. 


\section{Table 9. Different Use of Networks among Population with Complete Primary Education vs. Population with Incomplete Primary Education}

\begin{tabular}{|c|c|c|c|c|c|c|c|c|}
\hline & \multicolumn{4}{|c|}{ Female Sample } & \multicolumn{4}{|c|}{ Male Sample } \\
\hline & \multicolumn{2}{|c|}{ Urban } & \multicolumn{2}{|c|}{ Rural } & \multicolumn{2}{|c|}{ Urban } & \multicolumn{2}{|c|}{ Rural } \\
\hline & $(1)$ & $(2)$ & (3) & $(4)$ & $(5)$ & (6) & $(7)$ & $(8)$ \\
\hline \multicolumn{9}{|c|}{ Dependent variable: Labor market participation } \\
\hline $\begin{array}{l}\text { Average employed workers in the } \\
\text { neighborhoods }\end{array}$ & $\begin{array}{c}0.0003 \\
(0.0031)\end{array}$ & & $\begin{array}{c}0.0004 \\
(0.0014)\end{array}$ & & $\begin{array}{c}0.0031^{* *} \\
(0.0015)\end{array}$ & & $\begin{array}{l}-0.0000 \\
(0.0000)\end{array}$ & \\
\hline $\begin{array}{l}\text { Average employed workers in the } \\
\text { neighborhood*incomplete primary==1 }\end{array}$ & $\begin{array}{c}0.0009 \\
(0.0007)\end{array}$ & & $\begin{array}{c}0.0007 \\
(0.0008)\end{array}$ & & $\begin{array}{l}-0.0002 \\
(0.0002)\end{array}$ & & $\begin{array}{l}-0.0000 \\
(0.0000)\end{array}$ & \\
\hline $\begin{array}{l}\text { Average female employed in the } \\
\text { neighborhood }\end{array}$ & & $\begin{array}{c}0.0033 \\
(0.0029)\end{array}$ & & $\begin{array}{c}0.0002 \\
(0.0017)\end{array}$ & & $\begin{array}{c}0.0003 \\
(0.0010)\end{array}$ & & $\begin{array}{l}-0.0000 \\
(0.0000)\end{array}$ \\
\hline $\begin{array}{l}\text { Average female employed in the } \\
\text { neighborhood*incomplete primary==1 }\end{array}$ & & $\begin{array}{c}0.0006 \\
(0.0033)\end{array}$ & & $\begin{array}{c}0.0011 \\
(0.0017)\end{array}$ & & $\begin{array}{l}-0.0005 \\
(0.0009)\end{array}$ & & $\begin{array}{l}-0.0000 \\
(0.0000)\end{array}$ \\
\hline $\begin{array}{l}\text { Average male employed in the } \\
\text { neighborhood }\end{array}$ & & $\begin{array}{l}-0.0056 \\
(0.0042)\end{array}$ & & $\begin{array}{l}-0.0006 \\
(0.0018)\end{array}$ & & $\begin{array}{c}0.0033^{* *} \\
(0.0014)\end{array}$ & & $\begin{array}{c}0.0000 \\
(0.0000)\end{array}$ \\
\hline $\begin{array}{l}\text { Average male employed in the } \\
\text { neighborhood*incomplete primary==1 }\end{array}$ & & $\begin{array}{c}0.0003 \\
(0.0021)\end{array}$ & & $\begin{array}{l}-0.0004 \\
(0.0013)\end{array}$ & & $\begin{array}{c}0.0002 \\
(0.0006)\end{array}$ & & $\begin{array}{c}0.0000 \\
(0.0000)\end{array}$ \\
\hline \multicolumn{9}{|l|}{ Dependent variable: Wage/salary work } \\
\hline $\begin{array}{l}\text { Average wage/salary workers in the } \\
\text { neighborhood }\end{array}$ & $\begin{array}{c}0.0232^{* * *} \\
(0.0048)\end{array}$ & & $\begin{array}{c}0.0032 \\
(0.0024)\end{array}$ & & $\begin{array}{c}0.0003 \\
(0.0038)\end{array}$ & & $\begin{array}{c}0.0024 \\
(0.0022)\end{array}$ & \\
\hline $\begin{array}{l}\text { Average wage/salary workers in the } \\
\text { neighborhood*incomplete primary==1 }\end{array}$ & $\begin{array}{c}0.0077^{* * *} \\
(0.0025)\end{array}$ & & $\begin{array}{l}0.0039 * * \\
(0.0018)\end{array}$ & & $\begin{array}{c}0.0054^{* * *} \\
(0.0018)\end{array}$ & & $\begin{array}{l}0.0028 * \\
(0.0015)\end{array}$ & \\
\hline $\begin{array}{l}\text { Average female wage/salary workers in } \\
\text { the neighborhood }\end{array}$ & & $\begin{array}{l}0.0172 * * * \\
(0.0045)\end{array}$ & & $\begin{array}{c}0.0037 \\
(0.0036)\end{array}$ & & $\begin{array}{l}-0.0054 \\
(0.0046)\end{array}$ & & $\begin{array}{l}-0.0043^{*} \\
(0.0025)\end{array}$ \\
\hline $\begin{array}{l}\text { Average female wage/salary workers in } \\
\text { the neighborhood*incomplete } \\
\text { primary==1 }\end{array}$ & & $\begin{array}{c}0.0102 * * \\
(0.0050)\end{array}$ & & $\begin{array}{l}-0.0033 \\
(0.0043)\end{array}$ & & $\begin{array}{l}-0.0011 \\
(0.0040)\end{array}$ & & $\begin{array}{c}0.0030 \\
(0.0026)\end{array}$ \\
\hline $\begin{array}{l}\text { Average male wage/salary workers in } \\
\text { the neighborhood }\end{array}$ & & $\begin{array}{c}0.0041 \\
(0.0043)\end{array}$ & & $\begin{array}{c}0.0004 \\
(0.0031)\end{array}$ & & $\begin{array}{c}0.0040 \\
(0.0034)\end{array}$ & & $\begin{array}{l}0.0038^{* *} \\
(0.0016)\end{array}$ \\
\hline $\begin{array}{l}\text { Average male wage/salary workers in } \\
\text { the neighborhood*incomplete } \\
\text { primary==1 }\end{array}$ & & $\begin{array}{c}0.0006 \\
(0.0029)\end{array}$ & & $\begin{array}{l}0.0052 * \\
(0.0031)\end{array}$ & & $\begin{array}{c}0.0044 * * \\
(0.0022)\end{array}$ & & $\begin{array}{c}0.0002 \\
(0.0014)\end{array}$ \\
\hline
\end{tabular}

Results express marginal probabilities.Weighted estimates. Robust standard errors in parentheses. * significant at $10 \%$; ** significant at $5 \%$; *** significant at $1 \%$ The regressions presented in this table include the same controls for individual characteristics, household's characteristics, contextual and municipality fixed effects as the ones presented in Tables 5 - 8; not shown in this table. 


\section{Figure 1. Probability of Working as a Wage/Salary Worker as a Function of the Share of Wage/Salary Workers in the Neighborhood}
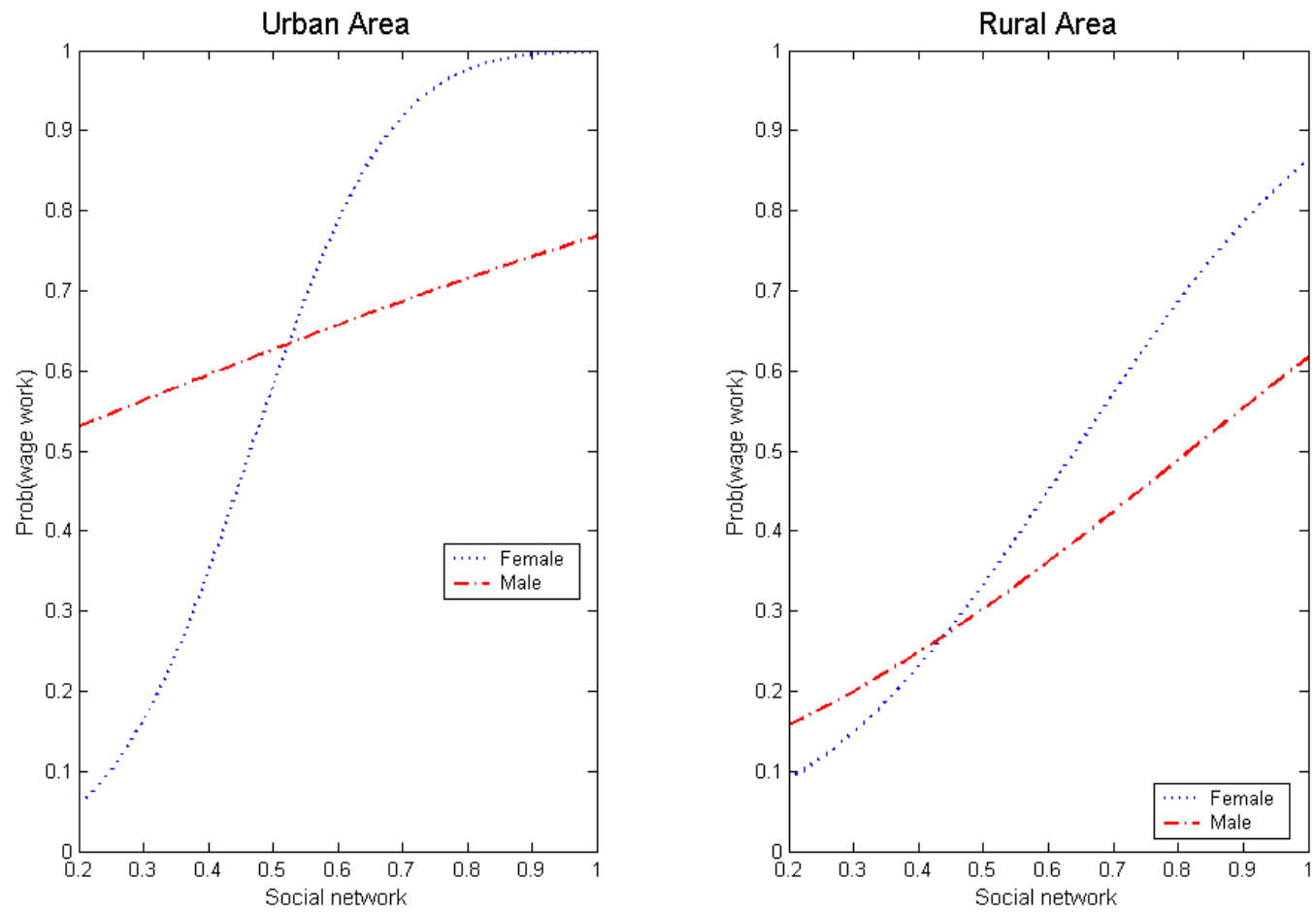

Note: The probability of working as a wage/worker is calculated using the results presented in column (4) of Tables 6 to 10, using fixed effects and controls for contextual effects. The value of the average group-sample is used for all variables, except for the social network variable which varies. 


\section{Figure 2. Probability of Working as a Wage/Salary Worker as a Function of the Share of Wage/Salary Female and Male Workers in the Neighborhood}
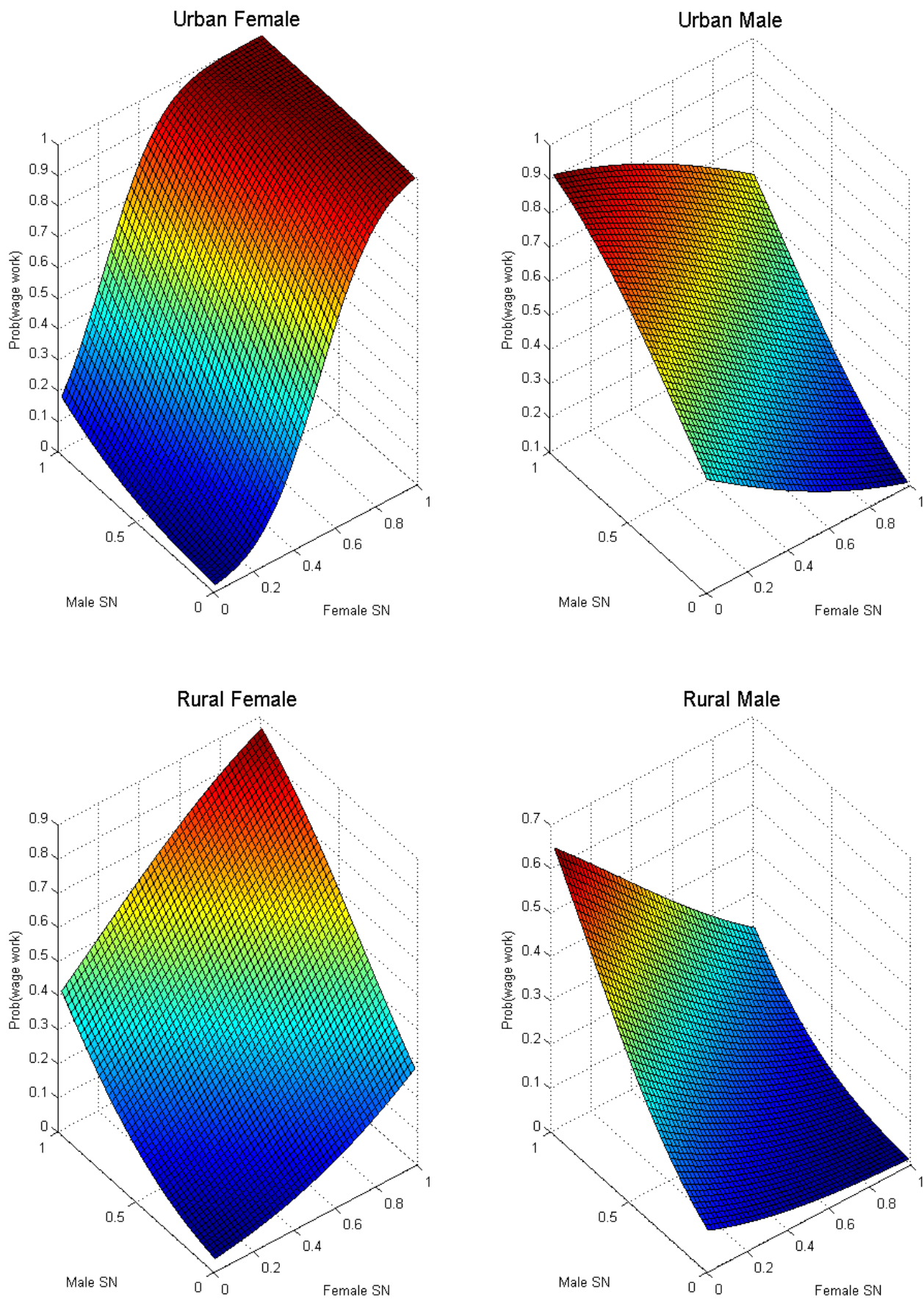

Note: The probability of working as a wage/worker is calculated using the results presented in column (6) of Tables 6 to 10, using fixed effects and controls for contextual effects. The value of the average group-sample is used for all variables, except for the social network variable, which varies. 